\title{
Arsenic and Heavy Metal Uptake and Accumulation in Native Plant Species from Soils Polluted by Mining Activities
}

\author{
Sara García-Salgado - David García-Casillas • \\ Ma. Angeles Quijano-Nieto. \\ Ma. Milagros Bonilla-Simón
}

\begin{abstract}
Arsenic and heavy metal (specifically Cd, $\mathrm{Cr}, \mathrm{Cu}, \mathrm{Ni}, \mathrm{Pb}$, and $\mathrm{Zn}$ ) uptake, translocation, and accumulation in ten native plant species spontaneously growing in soils polluted by mining activities were studicd, with a focus on future phytoremediation work in polluted soils. Plant and soil samples werc collcetcd in the vicinity of the Mónica mine (NW Madrid, Spain). Soil analysis showed the ability of native plants for growing in soils with high concentration levels of $\mathrm{Cd}$, $\mathrm{Cu}, \mathrm{Pb}, \mathrm{Zn}$, and especially As. From these elements, the highest percentage of extractable elements was found for $\mathrm{Cd}$ and the lowest for $\mathrm{Pb}$. A highly significant correlation was observed between total and extractable element concentrations in soils, except for $\mathrm{Cu}$, indicating that total concentration is the most relevant factor for element mobility in these soils. Extractable elements in soils were better correlated with concentrations in plants than total elements in soils; thus, extraction methods applied are suitable to estimate the element phytoavailable fraction in soils, which depends on the plant species and not only on the element mobility in soils. High element concentrations were found in
\end{abstract}

S. García-Salgado - D. Garcia-Casillas *

M. A. Quijano-Nicto · M. M. Bonilla-Simón

Departamento de Ingeniería Civil: Tecnologia Hidráulica y

Energética, Escuela Universitaria de Ingeniería Técnica de

Obras Públicas, Universidad Politécnica de Madrid,

Alfonso XII 3 y 5 ,

28014 Madrid, Spain

e-mail: mariau.quijauo@upm.es the aboveground parts of Corrigiola telephiifolia (As and $\mathrm{Pb}$ ), Jasione montana ( $\mathrm{Cd}$ and $\mathrm{Zn}$ ), and Digitalis thapsi ( $\mathrm{As}, \mathrm{Cd}, \mathrm{Cu}, \mathrm{Pb}$ and $\mathrm{Zn}$ ). However, considering the translocation and accumulation factors, together with the concentration levels found in roots and aboveground parts, only $C$. telephiifolia could bc considered a $\mathrm{Pb}$ accumulator and an As hyperaccumulator plant, which could be used for future phytoremediation work in soils polluted with As.

Keywords Arsenic · Heavy metals · Mining soils . Native plants Accumulator plants . Corrigiola telephiifolia

\section{Introduction}

Arsenic is a highly toxic metalloid of great environmental concem due to extensive contamination resulting from a wide range of activities (Bhattacharya et al, 2007). Arsenic mining is one example of these activitics, as soil and water around mines contain increased concentrations of arsenic as well as heavy metals (Antosiewicz et al. 2008; Sridhar et al. 2007). In addition, several studics have reported a high degree of arsenic and/or heavy metal pollution in soils affected by the oxidation of pyritic materials (Alvarenga et al. 2004; Antosiewicz et al. 2008; Moreno-Jiménez et al. 2009,2010 ). The risks for both environment and human health from arsenic and toxic heavy metals (specifically $\mathrm{Cd}, \mathrm{Cr}, \mathrm{Cu}, \mathrm{Ni}, \mathrm{Pb}$, and $\mathrm{Zn}$ ) are associated 
with the forms bioavailable to plants (Kabata-Pendias 2004; Zhao et al. 2009).

Selective extraction methods can assess the amounts of mobile or potentially mobile metallic species, which may comelate with plant-available contents under certain environmental conditions (Anawar et al. 2008; Menzies et al. 2007; Rao et al. 2008). Several studies have shown the suitability of weak neutral salt solutions as metal extractants in soils because they can be considered good models for simulating rainfall and flooding events. Although there is no established standard method for these types of studies, the use of a $0.01-\mathrm{mol} \mathrm{L}^{-1}$ calcium chloride solution is widely recommended for the leaching of heavy metals present in exchangeable fractions of soils (Houba et al. 2000; Kabata-Pendias 2004; Pueyo et al. 2004, 2005; Sahuquillo et al. 2003; Takeda et al. 2006). Similarly, phosphate or acetate solutions have been reported to be better extractants for estimating the bioavailable arsenic in contaminated soils (Anawar et al. 2008; Antosiewicz et al. 2008; Moreno-Jiménez et al. 2010).

Some plants that grow on metalliferous soils have developed the ability to accumulate high levels of metals in their tissues without symptoms of toxicity (Lasat 2002; Pilon-Smits 2005). Those plants that are able to take up and accumulate high concentrations of heavy metals and metalloids are called hyperaccumulators. It has been established that a hyperaccumulator plant must be able to accumulate $\mathrm{Cd}>100 \mathrm{mg} \mathrm{kg}^{-1}$; $\mathrm{As}, \mathrm{Cu}, \mathrm{Ni}$, and $\mathrm{Pb}$ $>1,000 \mathrm{mg} \mathrm{kg}^{-1}$; and $\mathrm{Zn}>10,000 \mathrm{mg} \mathrm{kg}^{-1}$ in their shoot dry matter (Haque et al. 2008; Kabata-Pendias 2001). Research on arsenic and heavy metal hyperaccumulator plants has been extensively developed. Detailed information concerning hyperaccumulator species can be found in several reviews (Alkorta et al. 2004; Butcher 2009; Padmavathiamma and Li 2007; Vamerah et al. 2010). The most proficient plants at accumulating arsenic seem to be fern species such as Pteris vitata and Pityrogramma calomelanos, which can accumulate more than $8,000 \mu \mathrm{g} \mathrm{g}^{-1}$ As in the fronds. Nevertheless, most of the known hyperaccumulator plants present serious limitations becanse they are usually specific for one particular metal and grow under specific environmental conditions (Gisbert et al. 2008).

Plants growing in metalliferous soils may have exceptional properties that make them interesting for phytoremediation because these indigenous plant species are often better suited for survival, growth, and reproduction under environmental extremes than plants introduced from other environments (Mahmud et al. 2008; Pilon-Smits 2005). As such, soil/plant metal transfer in native plant species growing in areas polluted by mining activities has been previously studied by several authors. For example, Alvarenga et al. (2004) reported the Mn accumulator capacity of the native aromatic bush Cistus ladanifer in the mining region of Aljustrel (Portugal), whereas Moreno-Jiménez et al. (2009) reported the $\mathrm{Cd}$ and $\mathrm{Zn}$ accumulator capacity of Salix atrocinerea and Digitalis thapsi from the Mónica mine surroundings (Bustarviejo, Madrid). Additionally, Antosiewicz et al. (2008) assessed the ability of several native plant species from an arsenic/gold mine in Zloty Stok (Poland) to modify the amount of bioavailable As in their rhizosphere, reporting the potential of Calamagrostis arundinacea for phytoremediation and of Stachys sylvatica for phytostabilization. Furthermore, Haque et al. (2008) reported the Cu hyperaccumulator capacity of the desert broom Baccharis sarothroides Gray growing on mine taihings in Arizona (USA); this plant can be also considered a $\mathrm{Mo}, \mathrm{Cr}$, and $\mathrm{Zn}$ accumulator:

Taking into account that hyperaccumulator plants can be identified from native species spontaneously growing on polluted soils and therefore be useful for phytoremediation purposes, concentrations of arsenic and heavy metals (specifically $\mathrm{Cd}, \mathrm{Cr}, \mathrm{Cu}, \mathrm{Ni}, \mathrm{Pb}$, and $\mathrm{Zn}$ ) in native plants and the soils below them from an abandoned arsenic mining area were determined by inductively coupled plasma atomic emission spectrometry (ICP-AES). In the present work, the main objectives were: (1) to characterize plants that are able to grow and survive in polluted soils by mining activities and (2) to study the translocation, accumulation, and bioavailability factors of these plant species in order to identify them as heavy metal/ metalloid hyperaccumulators, with a focus on future phytoremediation work in polluted soils.

\section{Materials and Methods}

\subsection{Instrumentation}

A pH meter (Metrohm model 827, Herisau, Switzerland) and a $\mathrm{pH}$ electrode (Metrohm model LL Sohtrode 
Pt1000) were used to measure the soil $\mathrm{pH}$. A conductivity meter (Crison model Basic 30+, Barcelona, Spain) and a conductivity cell (Crison model 5070 ) were used to measure the soil conductivity.

A drying oven from Binder GmbH (Tuttlingen, Germany), model ED53, was used to dry soil and plant samples, and a mixer mill (Retsch model MM 301, Haan, Germany) was used to grind the plant samples using tungsten carbide grinding jars and balls. Stainless steel test sieves between $4 \mathrm{~mm}$ and $63 \mu \mathrm{m}$ nominal apertures (Cisa, Barcelona, Spain) were used for the sieving of soil samples.

A mechanical shaker (Ika model RS/OS 10 , basic yellow line, Staufen. Germany) was used to carry out the soil extractions, and a centrifuge (Eppendorf model 5804 R, Hamburg. Germany) was used for the centrifugation of the soil extracts.

An ETHOS 1 closed vessel microwave digestion system (Milestone S.r.l., Sorisole, BG, Italy), with built-in ATC-400-CE automatic temperature control and employing TFM-Teflon microwave vessels, was used for the digestion of plant and soil samples.
A Varian model Liberty Series II axial sequential inductively coupled plasma atomic emission spectrometer (Mulgrave, Australia) was used for ICP-AES measurements. A PS Analytical Millennium Excalibur (Kent, UK) atomic fluorescence spectrometer, with sample introduction by hydride generation (HG-AFS), was employed for the determination of arsenic contents lower than the limit of quantification by ICP-AES. Experimental conditions are summarized in Table 1.

\subsection{Reagents and Standard Solutions}

All solutions were prepared using deionized water obtained from a Millipore water purification system (Elix ${ }^{2}$, Molsheim, France). The concentrated acids $\mathrm{HNO}_{3}(69.5 \%)$ and $\mathrm{HCl}(37 \%)$, as well as $\mathrm{H}_{2} \mathrm{O}_{2}$ (35\%), all from Scharlab (Barcelona, Spain), were used to prepare the corresponding digestion mixtures. Soil extractions were carried out with a $0.01-\mathrm{mol} \mathrm{L}^{-1}$ $\mathrm{CaCl}_{2}$ solution for $\mathrm{Cd}, \mathrm{Cr}, \mathrm{Cu}, \mathrm{Ni}, \mathrm{Pb}$, and $\mathrm{Zn}$, and with a $0.1-\mathrm{mol} \mathrm{L}^{-1}$ phosphate buffer solution $(\mathrm{pH}=$ 7.2) for As. The extractant solutions were prepared
Table 1 Experimental conditions for the determination of total $\mathrm{As}, \mathrm{Cd}, \mathrm{Cr}$, $\mathrm{Cu}, \mathrm{Ni}, \mathrm{Pb}$, and $\mathrm{Zn}$ by IC.P-AES and total As by HG-AFS

\begin{tabular}{|c|c|}
\hline \multicolumn{2}{|l|}{ IC.P-AES } \\
\hline Forward power (W) & 1,200 \\
\hline Photomultiplier tube voltage (V) & 650 \\
\hline Nebulization argon pressure $(\mathrm{kPa})$ & 240 \\
\hline Auxiliary argon flow rate $\left(\mathrm{L} \mathrm{min}^{-1)}\right.$ & 1.50 \\
\hline Coolant argon flow rate $\left(\mathrm{L} \mathrm{min}^{-1}\right)$ & 15.0 \\
\hline Nebulizer type & V-groove \\
\hline Wayelengths (nm) & $\begin{array}{l}\text { As } 188.979, \text { Cd } 226.502, \text { Cr } 267.716 \text {, } \\
\text { Cu } 324.754, \mathrm{Ni} 352.454, \mathrm{~Pb} 220.353 \\
\text { Zn } 206.200\end{array}$ \\
\hline \multicolumn{2}{|l|}{ HG-AFS } \\
\hline Wavelength (nm) & 197.3 \\
\hline Primary cuntent (mA) & 27.5 \\
\hline Boost cuntent (mA) & 35 \\
\hline Delay time (s) & 10 \\
\hline Analysis time (s) & 10 \\
\hline Memory time (s) & 40 \\
\hline $\mathrm{HCl}\left(\mathrm{mol} \mathrm{L}^{-1}\right)$ & 3.0 \\
\hline $\mathrm{NaBH}_{4} \%(w / v)$ & 1.0 \\
\hline Ar flow rate $\left(\mathrm{mL} \mathrm{min}{ }^{-1}\right)$ & 250 \\
\hline Air flow rate ( $\left.\mathrm{L} \mathrm{min}^{-1}\right)$ & 2.5 \\
\hline Carrier flow rate $\left(\mathrm{mL} \mathrm{min}^{-1}\right)$ & 9.0 \\
\hline $\mathrm{NaBH}_{4}$ llow rate $\left(\mathrm{mL} \mathrm{min}^{-1}\right)$ & 4.5 \\
\hline
\end{tabular}


from solid $\mathrm{CaCl}_{2}$ or $\mathrm{KH}_{2} \mathrm{PO}_{4}$ and $\mathrm{K}_{2} \mathrm{HPO}_{4}$, obtained from Scharlab, in deionized water.

Liquid standard stock solutions for ICP (TraceCERT $^{\overline{\mathrm{B}}}$ Ultra) of $1,000 \pm 2 \mathrm{mg} \mathrm{L}^{-1} \mathrm{Cd}, \mathrm{Cr} ; \mathrm{Ni}, \mathrm{Pb}$, and $\mathrm{Zn}, 994 \pm 2 \mathrm{mg} \mathrm{L}^{-1} \mathrm{As}$, and $998 \pm 4 \mathrm{mg} \mathrm{L}^{-1} \mathrm{Cu}$, obtained from Fluka (Sigma-Aldrich, Steinheim, Germany), were used for multielement analysis. Standard working solutions were prepared daily by dilution in $2 \% \mathrm{HNO}_{3}(v / v)$. Finally, liquid standard stock solutions of $1,000 \mathrm{mg} \mathrm{L}^{-1} \mathrm{Rh}$ and $\mathrm{Y}$ were used as an internal standard for ICP-AES multielement analysis of soil and plant samples, respectively.

A solution containing $5 \%(w / v) \mathrm{KI}$ and $5 \%(w / v)$ ascorbic acid was used as the reducing solution prior to As determination by HG-AFS. A $3.0-\mathrm{mol} \mathrm{L}^{-1} \mathbf{H C l}$ solution and a $1 \%(w / v) \mathrm{NaBH}_{4}$ dissolved in $0.1 \mathrm{~mol} \mathrm{~L}^{-1} \mathrm{NaOH}$ solution (all solid products from Sigma-Aldrich) were used to generate the arsenic hydrides.

\subsection{Site Description and Collection of Samples}

The area studied corresponded to the surroundings of the Mónica mine, located in the northwestern part of the village of Bustarviejo. This village is situated in the northern part of Madrid (Spain) at $62 \mathrm{~km}$ from the metropolitan area. The mine was exploited fiom the seventeenth to the twentieth century, first for silver (matildite) and then for arsenic (arsenopyrite) extraction. The mineralogy is characterized by the dominance of pyrite $\left(\mathrm{FeS}_{2}\right)$, which is associated with other ore minerals (sulfides), the most important of which are arsenopyrite (FeAsS), sphalerite $(\mathrm{ZnS})$, chalcopyrite $\left(\mathrm{CuFeS}_{2}\right)$, and galena ( $\mathrm{PbS}$ ) (González del Tanago-Chanrai and González del Tanago-del Río 2002; Jiménez et al. 2004). In addition, arsenic and heavy metal contamination of the mine surroundings has been reported previously (Moreno-Jiménez et al. 2009, 2010; Pastor et al. 2008; Pastor and Hernández 2008). Monitoring metal pollution level in these soils is now necessary because the area has been classified as a leisure site inside an environmental reservoir proposed for the ecological network Natura 2000, following the environmental directives of the European Union (92/43/CEE/Directive). The vegetation of the area in the lower zones is characterized by an open forest, Quercus pyrenaica being the most abundant native species; in the upper zones, and therefore in the mining area, the vegetation is dominated by annual and perennial herbs (Agrostis sp., Arrhenatherum sp., Rumex sp.) and woody plants (Cytisus sp., Thymus sp.) (Moreno-Jiménez et al. 2009; Pastor et al. 2008).

Soil and plant sampling was performed in the Mónica mine surroundings between June and July 2008 and May 2009, in different sampling sites affected by former mining activities (close to the shaft of the mine and to the areas where smelting procedures and ore glinding were cartied out), located between the geographic coordinates $40^{\circ} 52^{\prime}$ $02.42^{\prime \prime} \mathrm{N}, 3^{\circ} 43^{\prime} 46.79^{\prime \prime} \mathrm{W}$ and $40^{\circ} 52^{\prime} 11.43^{\prime \prime} \mathrm{N}, 3^{\circ} 43^{\prime}$ $41.68^{\prime \prime} \mathrm{W}$, being the extension of this area of approximately $20,000 \mathrm{~m}^{2}$. Taking into account previous studies conducted on 39 plant species of this same area (García-Salgado et al. 2009; Pastor et al. 2008), several different plant species were collected (between three and five plants of each species) as well as the soil below them. The plant samples studied were Arrhenatherum album, Corrigiola telephilfolia, Cynosorus echinatus, Digitalis thapsi, Holcus mollis, Jasione montana, Plantago lanceolata, Rumex acetosella, Thymus zygis, and Trisetum ovatum. Three of these plant species (A. album, P. lanceolata, and $R$. acetosella) and their conesponding soils were also collected separately of mine surroundings. This area, which was considered unpolluted from this point, is located at $500 \mathrm{~m}$ north of the mine and at higher altitude (about $100 \mathrm{~m}$ ), between the geographic coordinates $40^{\circ} 52^{\prime}$ $26.34^{\prime \prime} \mathrm{N}, 3^{\circ} 43^{\prime} 47.80^{\prime \prime} \mathrm{W}$ and $40^{\circ} 52^{\prime} 26.97^{\prime \prime} \mathrm{N}, 3^{\circ} 43^{\prime}$ $52.32^{\prime \prime} \mathrm{W}$. Once the plants were removed from the ground, soils below them were collected up to a depth of approximately $30 \mathrm{~cm}$.

Prior to the analysis of the plant material, aboveground parts (leaves and shoots) and roots were carefully separated, thoroughly washed with tap water, and rinsed three times with deionized water to remove any surface soil particles or dust deposits attached to the plant surfaces (Moreno-Jiménez et al. 2009). After washing, the samples were dried at $50^{\circ} \mathrm{C}$ for 7 days, and the dried tissues were weighed and ground into fine powder prior to analysis.

Soil samples were air-dried at room temperature and sieved through $4 \mathrm{~mm}-63 \mu \mathrm{m}$ mesh for a particle size study. Separately, the $<2 \mathrm{~mm}$ fraction was collected for the determination of $\mathrm{pH}$, conductivity, moisture, and organic matter; whereas the $<90 \mu \mathrm{m}$ fraction was collected to carry out the chemical analysis of soil samples. 


\subsection{Procedures}

\subsubsection{Analysis of Soil and Plant Samples}

The electric conductivity, $\mathrm{pH}$, moisture, and the dichromate-oxidizable organic matter content of soil samples were determined following the procedures described in the Spanish standards for soils (UNE 77308 2001; UNE 77305 1999; UNE 103-300 1993; MAPA 1994).

Soil and plant samples (aboveground parts and roots separately) were digested in a microwave oven for multielement analysis by ICP-AES. Approximately $250 \mathrm{mg}$ of sample was weighed and placed into a Teflon reaction vessel with $10 \mathrm{~mL}$ of the appropriate acid mixhture $\left(\mathrm{HCl} / \mathrm{HNO}_{3}(3: 1, v / v)\right.$ and $\mathrm{HNO}_{3} / \mathrm{H}_{2} \mathrm{O}_{2}(1: 1$, $v / v)$ for soil and plant samples, respectively). The microwave digestion method applied a temperature slope of $200^{\circ} \mathrm{C}$ over 15 min with a hold time of $10 \mathrm{~min}$. The soil digests were filtered through an ash-free paper filter, and $2 \mathrm{mg} \mathrm{L} \mathrm{L}^{-1} \mathbf{R h}$ was added as an internal standard. For the plant digests, $1 \mathrm{mg} \mathrm{L}^{-1} \mathrm{Y}$ was added to the samples as an internal standard. Finally, the digests were diluted with deionized water up to $50 \mathrm{~mL}$ and stored at $+4^{\circ} \mathrm{C}$ in polyethylene containers until analysis. Three replicates of every sample were digested, together with the contesponding blanks.

Total element concentrations were determined by ICP-AES by external calibration with internal standardization (with $\mathrm{Rh}$ or $\mathrm{Y}$ for soils and plants, respectively). Arsenic contents lower than the limit of quantification in ICP-AES $\left(30 \mu \mathrm{g} \mathrm{L}^{-1}\right)$ were analyzed by HG-AFS. For this purpose, $2.5 \mathrm{~mL}$ of a 3 -mol L $\mathrm{L}^{-1} \mathrm{HCl}$ solution and $2.5 \mathrm{~mL}$ of the reducing solution were added to the digested samples, the volume was diluted to $25 \mathrm{~mL}$ with deionized water, and total As was determined by HG-AFS the following day by external calibration, under experimental conditions shown in Table 1. All final results were blank subtracted, when it was quantifiable, to compensate for possible elemental interference from the blank.

\subsubsection{Exiraction of Soil Samples}

The $\mathrm{CaCl}_{2}$ and phosphate extraction methods were based on those proposed by Pueyo et al. (2005) and Antosiewicz et al. (2008), respectively. Briefly, ap- proximately $2 \mathrm{~g}$ of soil sample was weighed into a centrifuge tube, and $20 \mathrm{~mL}$ of a $0.01-\mathrm{mol} \mathrm{L}^{-1}$ $\mathrm{CaCl}_{2}$ solution (or $20 \mathrm{~mL}$ of a $0.1-\mathrm{mol} \mathrm{L}^{-1} \mathrm{KH}_{2} \mathrm{PO}_{4} /$ $0.1-$ mol $\mathrm{L}^{-1} \mathrm{~K}_{2} \mathrm{HPO}_{4}$ solution at $\mathrm{pH} 7.2$ for As extraction) was added. The mixture obtained was shaken, at room temperature, for $2 \mathrm{~h}$ at $30 \mathrm{rpm}$. After shaking, the extract was separated from the solid residue by centrifugation at $14,000 \times \mathrm{g}$ for $10 \mathrm{~min}$, and $2 \mathrm{mg} \mathrm{L}^{-1} \mathbf{R h}$ was added as an internal standard. The final extracts were diluted with deionized water up to $25 \mathrm{~mL}\left(\mathrm{CaCl}_{2}\right.$ extracts were acidified with $\mathrm{HNO}_{3}$ up to a final concentration of $2 \%(v / v))$ and immediately analyzed by ICP-AES. Three replicates of every sample were extracted, together with the corresponding blanks. In addition, arsenic contents lower than the limit of quantification in ICP-AES were analyzed by HG-AFS. All final results were blank subtracted, when it was quantifiable, to compensate for possible elemental interference from the blank.

\subsubsection{Analytical Characteristics in ICP-AES and $H G-A F S$}

The precision of the method by ICP-AES, expressed as relative standard deviation (\%RSD), was estimated from five replicate measurements of a standard solution containing $500 \mu \mathrm{g} \mathrm{L}^{-1} \mathrm{As} ; 50 \mu \mathrm{g} \mathrm{L}^{-1} \mathrm{Cu}$, $\mathrm{Ni}, \mathrm{Pb}$, and $\mathrm{Zn}$; and $5 \mu \mathrm{g} \mathrm{L}^{-1} \mathrm{Cd}$ and $\mathrm{Cr}$; whereas in HG-AFS, a standard solution containing $0.5 \mu \mathrm{g} \mathrm{L}^{-1}$ As was used. In all cases, \%RSDs were lower than $5 \%$. The limits of detection were calculated as three times the standard deviation obtained from ten replicate blank determinations, whereas the limits of quantification (LOQ) were calculated as ten times the standard deviation obtained from ten replicate blank determinations, according to IUPAC definitions. The blank solutions used were the corresponding acid mixtures (digestion methods) or extractant solutions (soil extraction methods). LOQs obtained were in the range of $0.02 \mu \mathrm{g} \mathrm{g}^{-1}$ (for $\mathrm{Cd}$ ) and $3.6 \mu \mathrm{g} \mathrm{g}^{-1}$ (for $\mathrm{Ni}$ ) by ICP-AES and $0.02 \mu \mathrm{g} \mathrm{g}^{-1}$ for As determination by HG-AFS.

Different certified reference materials (CRMs) were used for the validation of the analytical methods used: CRM048-050 (sand soil) from RTC (Wyoming, USA), CRM BCR-483 (sewage sludge amended soil) from the Institute for Reference Materials and Measurements (Geel, Belgium), and CTA-VTL-2 (Virginia tobacco leaves) from the Institute of Nuclear 
Chemistry and Technology (Warszawa, Poland) were used for quality control of analytical data of total soil, extractable soil, and total plant content determinations, respectively.

\section{Results and Discussion}

3.1 Optimization of the Digestion Method for Plant Samples and Validation of the Analytical Methods on Soil Samples

The optimization of the microwave digestion method for multielement determination by ICP-AES in plant samples was carried out on the certified reference material CTA-VTL-2 (Virginia tobacco leaves), testing several acid digestion mixtures $\left(\mathrm{HNO}_{3}, \mathrm{HCl} / \mathrm{HNO}_{3}\right.$ $(3: 1, v / v)$ and $\left.\mathrm{HNO}_{3} / \mathrm{H}_{2} \mathrm{O}_{2}(1: 1, v / v)\right)$. From the results (Table 2), the microwave digestion with $\mathrm{HNO}_{3} / \mathrm{H}_{2} \mathrm{O}_{2}$ $(1: 1, v / v)$ was suitable for the determination of $\mathrm{Cd}, \mathrm{Cr}$. $\mathrm{Cu}, \mathrm{Pb}$, and $\mathrm{Zn}$ because no significant differences, at the $95 \%$ confidence level, were observed between the certified values and the experimental values for the CRMs, as well as for Ni determination, although it was necessary to increase the ratio of sample weight to final volume. This digestion mixture was also adequate for As determination by HG-AFS, which was required due to the low As concentration present in the CRM.

Table 3 shows the results obtained on the certified reference materials CRM048-050 (sand soil) and CRM BCR-483 (sewage sludge amended soil) used for the validation of the analytical methods applied to soil samples (aqua regia digestion method and calcium chloride extraction method, respectively). The results obtained showed the absence of signifi- cant differences, at the $95 \%$ confidence level, between the certified values (indicative values for CRM BCR483) and the experimental values for all the elements analyzed.

From the statistical results obtained, the proposed methods were adequate for total arsenic and heavy metal determinations in plants, as well as total and extractable element determinations in soils.

\subsection{Characterization and Multielement Analysis of Soil and Plant Samples}

Soil samples had $\mathrm{pH}$ values between 4.3 and 5.3 and low electric conductivity values $\left(30-100 \mu \mathrm{S} \mathrm{cm}^{-1}\right)$. and the dichromate-oxidizable organic matter was between $0.2 \%$ and $2 \%$. Moisture values obtained were lower than $4 \%$. The soil particle size sieve showed gravel percentages $(>4 \mathrm{~mm})$ of $25-46 \%$, sand percentages ( $4-0.063 \mathrm{~mm})$ of $49-70 \%$, and very low silt-clay percentages $(<63 \mu \mathrm{m}$, between $2 \%$ and $10 \%$ ). Therefore, the soils surrounding the mine were acidic, mainly sandy, low in clay, and with low levels of organic matter.

Element concentrations in roots and aboveground parts of the plant species collected and in the soils below them are shown in Table 4. The results obtained for Ni are not included because Ni concentrations in soils were lower than the medium reference value (VR90) in the Comunidad Autonoma de Madrid (CAM) (21 $\mathrm{kg} \mathrm{g}^{-1}$, ORD 2770/2006 MAD 2006), whereas $\mathrm{Ni}$ concentrations in plants were lower or close to the limit of quantification in ICP$\operatorname{AES}\left(3.6 \mu \mathrm{g} \mathrm{g}^{-1}\right)$.

Soil analysis showed $\mathrm{Cr}$ concentrations lower than the VR90 in CAM (32 $\left.\mathrm{Hg} \mathrm{g}^{-1}\right)$, while $\mathrm{Cd}, \mathrm{Cu}, \mathrm{Pb}$, and

Table 2 Results in micrograms per gram, mean (standard deviation) $n=3$, oblained for CTA-VTL-2 (Virginia tobacco leaves) for ICPAES element detemination, obtained by digestion in a microwave oven with three different acid mixtures

\begin{tabular}{|c|c|c|c|c|c|c|c|c|c|}
\hline & & & As & $\mathrm{Cd}$ & $\mathrm{Cr}$ & $\mathrm{Cu}$ & $\mathrm{Ni}$ & $\mathrm{Pb}$ & Zn \\
\hline \multirow[t]{4}{*}{$\begin{array}{l}\text { CTA- } \\
\text { VTL-2 }\end{array}$} & $\begin{array}{l}\text { Certified } \\
\text { value }\end{array}$ & & $0.969(0.072)$ & $1.52(0.17)$ & $1.87(0.16)$ & $18.2(0.9)$ & $1.98(0.21)$ & $22.1(1.2)$ & $43.3(2.1)$ \\
\hline & \multirow{3}{*}{$\begin{array}{l}\text { Expeninental } \\
\text { value }\end{array}$} & $\mathrm{HNO}_{3}$ & - & $0.86(0.03)$ & $1.00(0.02)$ & $13(1)$ & $1.93(0.01)^{b}$ & $16(4)$ & $32(2)$ \\
\hline & & $\begin{array}{c}\mathrm{HCl} / \mathrm{HNO}_{3} \\
(3: 1)\end{array}$ & - & $0.84(0.03)$ & $0.98(0.08)$ & $13.8(0.1)$ & $1.8(0.1)^{b}$ & $18.2(0.2)$ & $34(2)$ \\
\hline & & $\begin{array}{l}\mathrm{HNO}_{3} / \mathrm{H}_{2} \mathrm{O}_{2} \\
(1: 1)\end{array}$ & $0.86(0.08)^{a}$ & $1.43(0.03)$ & $1.94(0.08)$ & $17.1(0.3)$ & $2.0(0.2)^{b}$ & $24.7(0.2)$ & $40(1)$ \\
\hline
\end{tabular}

\footnotetext{
abtained by HG-AFS

${ }^{b}$ Ratio sample weigh/fiual volune $=1.0 \mathrm{~g} / 25 \mathrm{~mL}$
} 
Table 3 Results in micrograms per gram, mean (standard deviation) $n=3$, obtained for CRM048-050 (sand soil) and CRM BCR-483 (sewage sladge amended soil) for the validation of the ICP-AES analytical methods used for soil samples

\begin{tabular}{|c|c|c|c|c|c|c|c|c|}
\hline & & As & C.d & C.r & $\mathrm{Cu}$ & $\mathrm{Ni}$ & $\mathrm{Pb}$ & Zn \\
\hline \multicolumn{9}{|c|}{ Total concentrations by aqua regia digestion method } \\
\hline \multirow[t]{2}{*}{ CRM048-050 } & Certified value & $154(3.81)$ & $159(3.06)$ & $112(2.05)$ & $143(2.69)$ & $169(3.07)$ & $100(1.97)$ & $338(7.04)$ \\
\hline & Experimental value & $144(6)$ & $153(2)$ & $124(7)$ & $146(4)$ & $175(4)$ & $101(2)$ & $337(5)$ \\
\hline \multicolumn{9}{|c|}{ Extractable concentrations by calcium chloride extraction method } \\
\hline \multirow[t]{2}{*}{ CRM BCR-483 } & Indicative value & & $0.45(0.05)$ & $0.35(0.09)$ & $1.2(0.4)$ & $1.4(0.2)$ & & $8.3(0.7)$ \\
\hline & Experimental yalue & & $0.42(0.01)$ & $0.47(0.09)$ & $1.28(0.06)$ & $1.4(0.3)$ & & $8.0(0.4)$ \\
\hline
\end{tabular}

Zn concentration levels were generally higher than the corresponding reference values $\left(0.22 \mathrm{\mu g} \mathrm{g}^{-1}\right.$ for $\mathrm{Cd}$, $20 \mu \mathrm{g} \mathrm{g}^{-1}$ for $\mathrm{Cu}, 30 \mu \mathrm{g} \mathrm{g}^{-1}$ for $\mathrm{Pb}$, and $73 \mu \mathrm{g} \mathrm{g}^{-1}$ for $\mathrm{Zn}$ ), although they did not exceed maximum allowable concentrations (MAC) for industrial uses in CAM $\left(3 \cdot 10^{2} \mu \mathrm{g} \mathrm{g}^{-1}\right.$ for $\mathrm{Cd}, 8 \cdot 10^{3} \mu \mathrm{g} \mathrm{\textrm {g } ^ { - 1 }}$ for $\mathrm{Cu}$, $2.7 \cdot 10^{3} \mu \mathrm{g} \mathrm{g}^{-1}$ for $\mathrm{Pb}$, and $1 \cdot 10^{5} \mu \mathrm{g} \mathrm{g}^{-1}$ for $\mathrm{Zn}$ ) (ORD 2770/2006 MAD 2006), except for soils corresponding to the species C. echinatus, D. thapsi, $P$ lanceolata, and $T$ ovatum for $\mathrm{Pb}$. In the case of $\mathrm{As}$ concentrations in soils, they ranged from $3 \cdot 10^{2}$ to $3 \cdot 10^{4} \mu \mathrm{g} \mathrm{g}^{-1}$. Therefore, all soil samples exceeded the established MAC for industrial areas by CAM $\left(40 \mu \mathrm{g} \mathrm{g}^{-1}\right)$. These results agreed with those reported by Moreno-Jiménez et al. (2010), who found As concentrations up to $3 \cdot 10^{3} \mu \mathrm{g} \mathrm{g}^{-1}$ in soils near this mine. It was notewolthy that the soil below the plant species $R$. acetosella presented the highest arsenic concentration (approximately $3 \cdot 10^{4} \mu \mathrm{g} \mathrm{g}^{-1}$ ). This soil sample was from an old slagheap area of the Mónica mine, so it could not be considered as representative of the general contamination level of the mine surroundings. In the case of soils from the unpolluted area (data not shown), element concentrations found were lower than the reference values, except for $\mathrm{Cd}$ (concentrations between 1.5 and $2.1 \mathrm{\mu g} \mathrm{g}^{-1}$ ), although they were considerably lower than Cd concentrations found in most of the soils fiom the polluted area. Therefore, soils surrounding the Monica mine showed high levels of $\mathrm{Cd}$, $\mathrm{Cu}, \mathrm{Pb}$, and $\mathrm{Zn}$ and very high $\mathrm{As}$ concentrations, probably due to a soil enrichment in pyritic particles via transfer from the dumps.

Regarding plant samples, many of those collected from the polluted area (roots and/or aboveground parts) exceeded the maximum concentration normally found in plants for $\mathrm{Cd}\left(2 \mu \mathrm{g} \mathrm{g}^{-1}\right)$; $\mathrm{As}, \mathrm{Cr}$, and $\mathrm{Pb}$ $\left(5 \mu \mathrm{g} \mathrm{g}^{-1}\right)$; Cu $\left(25 \mu \mathrm{g} \mathrm{g}^{-1}\right)$; and $\mathrm{Zn}\left(400 \mu \mathrm{g} \mathrm{g}^{-1}\right)$
(Haque et al. 2008; Padmavathiamma and Li 2007). However, element concentrations in plant species from the unpolluted area (data not shown) were lower than these maximum concentrations considered normal in plants.

Cadmium, $\mathrm{Cr}$, and $\mathrm{Cu}$ were found mainly in roots. The highest $\mathrm{Cd}$ concentrations were found in the species D. thapsi and $J$. montana (about $100 \mathrm{\mu g} \mathrm{g}^{-1}$ ). which showed also the highest $\mathrm{Cd}$ levels in the aboveground parts (approximately $40 \mu \mathrm{g} \mathrm{g}^{-1}$ ). Similar $\mathrm{Cr}$ maximum levels in roots were found in the species A. album and H. mollis (about $100 \mu \mathrm{g} \mathrm{g}^{-1}$ ). However, the maximum $\mathrm{Cr}$ concentrations found in aboveground parts were about $10 \mu \mathrm{g} \mathrm{g}^{-1}$ (twice the normal level in plants), in the species A. album, C. echinatus, and $D$. thapsi. In the case of $\mathrm{Cu}$, the highest concentration was found in the species $A$ album $\left(427 \mu \mathrm{g} \mathrm{g}^{-1}\right)$, but it was retained in roots. A more efficient $\mathrm{Cu}$ translocation was observed in the species $D$. thapsi (95 and $193 \mu \mathrm{g} \mathrm{g}^{-1}$ in roots and aboveground parts, respectively) and $C$. telephiffolia (approximately $140 \mu \mathrm{g} \mathrm{g}^{-1}$ in both parts). This species, together with $P$ lanceolata and $R$. acetosella, showed $\mathrm{Cu}$ levels in aboveground parts higher than those considered normal in plants. Regarding $\mathrm{Zn}$, four plant species in roots and three in aboveground parts exceeded the normal levels in plants. The highest $\mathrm{Zn}$ concentrations were found in the roots of $A$ album $\left(2,320 \mu \mathrm{g} \mathrm{g}^{-1}\right)$ and in the aboveground parts of $D$. thapsi $\left(1,230 \mu \mathrm{g} \mathrm{g}^{-1}\right)$. Only the species $D$. thapsi and $J$ montana showed an efficient translocation of $\mathrm{Zn}$ at high concentration levels. In the case of $\mathrm{Pb}$ and $\mathrm{As}$, all plant species collected from the polluted area exceeded the nomal levels in plants, with the exception of the aboveground parts of $H$. mollis and $T$. ovatum for $\mathrm{Pb}$. The highest $\mathrm{Pb}$ concentrations were found in the roots of $A$. album $\left(480 \mu \mathrm{g} \mathrm{g}^{-1}\right)$ and the 
Table 4 Element concentrations in micrograms per gram, mean (standard deviation) $n=3$, in roots (R) and aboveground parts (AP) of native plants and soils below plants ( $S$ ) from the vicinity of the Mónica mine, obtained by microwave digestion and subsequent ICP-AES analysis

\begin{tabular}{|c|c|c|c|c|c|c|c|c|c|c|c|c|c|c|c|c|c|c|}
\hline \multirow[t]{2}{*}{ Flant species } & \multicolumn{3}{|l|}{ As } & \multicolumn{3}{|l|}{$\mathrm{Cd}$} & \multicolumn{3}{|l|}{$\mathrm{Cr}$} & \multicolumn{3}{|l|}{$\mathrm{Cu}$} & \multicolumn{3}{|l|}{$\mathbf{P b}$} & \multicolumn{3}{|l|}{$\mathrm{Zu}$} \\
\hline & $\begin{array}{l}\times 10^{2} \\
\mathbf{R}\end{array}$ & $\begin{array}{l}\times 10^{2} \\
\mathrm{AP}\end{array}$ & $\begin{array}{l}\times 10^{2} \\
\mathrm{~S}\end{array}$ & $\mathbf{R}$ & $\mathrm{AP}$ & $\mathrm{s}$ & $\mathbf{R}$ & $A P$ & $\mathrm{~s}$ & $\mathbf{R}$ & $A P$ & $\begin{array}{l}\times 10 \\
5\end{array}$ & $\mathrm{R}$ & $\mathrm{AP}$ & $\begin{array}{l}\times 10 \\
s\end{array}$ & $\begin{array}{l}\times 10^{2} \\
\mathbf{R}\end{array}$ & $\times 10^{2}$ & $\begin{array}{l}\times 10^{2} \\
S\end{array}$ \\
\hline Awhentheruth ollum & $\begin{array}{l}12.2 \\
(0.6)\end{array}$ & $\begin{array}{l}0.204 \\
(0.006)\end{array}$ & $\begin{array}{l}18.2 \\
(0.5)\end{array}$ & $\begin{array}{l}8.5 \\
(0.1)\end{array}$ & $\begin{array}{l}0.27 \\
(0.01)\end{array}$ & $\begin{array}{l}4.23 \\
(0.09)\end{array}$ & 93 & 10 & $\begin{array}{l}20.6 \\
(0.2)\end{array}$ & $\begin{array}{l}427 \\
\text { (3) }\end{array}$ & $\begin{array}{l}9.3 \\
(0.3)\end{array}$ & $\begin{array}{l}22.1 \\
(0.4)\end{array}$ & $\begin{array}{l}480 \\
(7)\end{array}$ & $\begin{array}{l}11.5 \\
(0.3)\end{array}$ & $\begin{array}{l}17.7 \\
(0.3)\end{array}$ & $\begin{array}{l}23.2 \\
(0.5)\end{array}$ & $\begin{array}{l}0.87 \\
(0.02)\end{array}$ & $\begin{array}{l}3.3 \\
(0.5)\end{array}$ \\
\hline Conigiola telephifotha & $\begin{array}{l}13.5 \\
(0.6)\end{array}$ & $\begin{array}{l}21.1 \\
(0.4)\end{array}$ & $\begin{array}{l}3.1 \\
(0.1)\end{array}$ & $\begin{array}{l}3.8 \\
(0.2)\end{array}$ & $\begin{array}{l}33 \\
(0.2)\end{array}$ & $\begin{array}{l}1.48 \\
(0.05)\end{array}$ & $\begin{array}{l}1.8 \\
(0.2)\end{array}$ & $\begin{array}{l}4.0 \\
(0.7)\end{array}$ & 14 & $\begin{array}{l}136 \\
(6)\end{array}$ & $\begin{array}{l}14] \\
(5)\end{array}$ & $\begin{array}{l}2.59 \\
(0.06)\end{array}$ & $\begin{array}{l}137 \\
(5)\end{array}$ & $\begin{array}{l}209 \\
\quad(9)\end{array}$ & $\begin{array}{l}1.2 \\
(0.2)\end{array}$ & $\begin{array}{l}2.40 \\
(0.07)\end{array}$ & $\begin{array}{l}3.10 \\
(0.09)\end{array}$ & $\begin{array}{l}0.94 \\
(0.06)\end{array}$ \\
\hline Cymosonus echmaths & $\begin{array}{l}8.1 \\
(0.2)\end{array}$ & $\begin{array}{l}0.60 \\
(0.02)\end{array}$ & $\begin{array}{l}49.3 \\
(0.8)\end{array}$ & $\begin{array}{l}4.0 \\
(0.2)\end{array}$ & $\begin{array}{l}1.24 \\
(0.01)\end{array}$ & $\begin{array}{l}53.1 \\
\quad(0.7)\end{array}$ & $\begin{array}{l}15 \\
(2)\end{array}$ & $\begin{array}{l}9.7 \\
(0.7)\end{array}$ & $\begin{array}{l}18.6 \\
(0.1)\end{array}$ & $\begin{array}{l}47 \\
\text { (2) }\end{array}$ & $\begin{array}{l}4.8 \\
\quad(0.5)\end{array}$ & $\begin{array}{l}309 \\
(6)\end{array}$ & $\begin{array}{l}128 \\
(5)\end{array}$ & 11 & $\begin{array}{l}275 \\
(3)\end{array}$ & $\begin{array}{l}3.07 \\
(0.06)\end{array}$ & $\begin{array}{l}1.38 \\
(0.05)\end{array}$ & $\begin{array}{l}153 \\
(3)\end{array}$ \\
\hline Digitatis thapsi & $\begin{array}{l}0.94 \\
(0.05)\end{array}$ & $\begin{array}{l}3.56 \\
(0.02)\end{array}$ & $\begin{array}{l}49.7 \\
(0.9)\end{array}$ & $\begin{array}{c}105.3 \\
(0.5)\end{array}$ & $\begin{array}{l}40.0 \\
(0.3)\end{array}$ & $\begin{array}{l}53.5 \\
(0.5)\end{array}$ & $\begin{array}{l}9.0 \\
(0.7)\end{array}$ & $\begin{array}{l}10.8 \\
(0.4)\end{array}$ & $\begin{array}{l}18.7 \\
(0.1)\end{array}$ & $\begin{array}{l}95 \\
\text { (1) }\end{array}$ & $\begin{array}{l}193 \\
(2)\end{array}$ & $\begin{array}{l}312 \\
\quad(5)\end{array}$ & ${ }_{(6)}^{171}$ & $\begin{array}{l}206 \\
\text { (2) }\end{array}$ & $\begin{array}{l}278 \\
\text { (4) }\end{array}$ & $\begin{array}{l}7.70 \\
(0.01)\end{array}$ & $\begin{array}{l}12.38 \\
(0.09)\end{array}$ & $\begin{array}{l}157 \\
(4)\end{array}$ \\
\hline Hotctus mollis & $\begin{array}{l}3.97 \\
(0.04)\end{array}$ & $\begin{array}{l}0.28 \\
(0.01)\end{array}$ & $\begin{array}{l}10.83 \\
(0.09)\end{array}$ & $\begin{array}{l}3.1 \\
(0.1)\end{array}$ & $\begin{array}{l}0.34 \\
(0.02)\end{array}$ & $\begin{array}{l}2.84 \\
(0.06)\end{array}$ & 82 & $\begin{array}{l}4.0 \\
(0.3)\end{array}$ & $\stackrel{28}{(1)}$ & $\begin{array}{l}95 \\
\text { (3) }\end{array}$ & $\begin{array}{l}6.3 \\
(0.5)\end{array}$ & $\begin{array}{l}6.80 \\
(0.03)\end{array}$ & $\begin{array}{l}65 \\
\text { (3) }\end{array}$ & n.d. & $\begin{array}{l}8.3 \\
(0.3)\end{array}$ & $\begin{array}{l}2.69 \\
(0.08)\end{array}$ & $\begin{array}{l}0.99 \\
(0.03)\end{array}$ & $\begin{array}{l}2.0 \\
(0.1)\end{array}$ \\
\hline Jasione montatar & $\begin{array}{l}1.50 \\
(0.04)\end{array}$ & $\begin{array}{l}0.83 \\
(0.03)\end{array}$ & $\begin{array}{l}26.9 \\
(0.1)\end{array}$ & $\begin{array}{l}90.6 \\
(0.6)\end{array}$ & $\begin{array}{l}39.2 \\
(0.7)\end{array}$ & $\begin{array}{l}2.6 \theta \\
(0.03)\end{array}$ & $\begin{array}{l}7.2 \\
(0.1)\end{array}$ & $\begin{array}{l}7.1 \\
(0.7)\end{array}$ & $\begin{array}{l}17.0 \\
(0.2)\end{array}$ & $\begin{array}{l}16.4 \\
(0.2)\end{array}$ & $\begin{array}{l}9.3 \\
(0.3)\end{array}$ & $\begin{array}{l}16.1 \\
(0.5)\end{array}$ & $\begin{array}{l}26.1 \\
(0.5)\end{array}$ & ${ }^{12}$ & $\begin{array}{l}32.4 \\
(0.6)\end{array}$ & $\begin{array}{l}3.09 \\
(0.05)\end{array}$ & $\begin{array}{l}5.21 \\
(0.09)\end{array}$ & $\begin{array}{l}2.5 \\
(0.1)\end{array}$ \\
\hline Plantugo lonteoluth & $\begin{array}{l}3.99 \\
(0.04)\end{array}$ & $\begin{array}{l}1.87 \\
(0.03)\end{array}$ & $\begin{array}{c}61.13 \\
(0.08)\end{array}$ & $\begin{array}{l}3.75 \\
\quad(0.06)\end{array}$ & $\begin{array}{l}1.5 \\
(0.2)\end{array}$ & $\begin{array}{l}48.91 \\
(0.02)\end{array}$ & $\begin{array}{l}9.3 \\
\quad(0.1)\end{array}$ & $\begin{array}{l}5.4 \\
\quad(0.1)\end{array}$ & $\begin{array}{c}13.7 \\
(0.6)\end{array}$ & $\begin{array}{l}123 \\
\text { (1) }\end{array}$ & 66 & $\begin{array}{l}295.8 \\
(0.1)\end{array}$ & $\begin{array}{l}121 \\
(8)\end{array}$ & $\begin{array}{l}65 \\
(5)\end{array}$ & $\begin{array}{r}271 \\
\quad(5)\end{array}$ & $\begin{array}{l}8.27 \\
\quad(0.08)\end{array}$ & $\begin{array}{l}4.13 \\
(0.05)\end{array}$ & $\begin{array}{l}159 \\
\text { (1) }\end{array}$ \\
\hline Rumex acetosella & $\begin{array}{l}11.2 \\
\quad(0.3)\end{array}$ & $\begin{array}{l}2.83 \\
\quad(0.07)\end{array}$ & $\begin{array}{l}325 \\
(4)\end{array}$ & $\begin{array}{l}4.9 \\
\quad(0.4)\end{array}$ & $\begin{array}{l}3.61 \\
\quad(0.04)\end{array}$ & $\begin{array}{l}9.9 \\
\quad(0.1)\end{array}$ & ${ }^{6}$ & $\begin{array}{l}4.8 \\
\quad(0.4)\end{array}$ & $\begin{array}{l}27.3 \\
(0.4)\end{array}$ & $\begin{array}{l}78 \\
\quad(5)\end{array}$ & 50 & $\begin{array}{l}109 \\
\text { (1) }\end{array}$ & $\begin{array}{l}122 \\
(7)\end{array}$ & $\begin{array}{l}90 \\
(5)\end{array}$ & $\begin{array}{r}211 \\
(4)\end{array}$ & $\begin{array}{l}1.80 \\
(0.06)\end{array}$ & $\begin{array}{l}1.62 \\
(0.05)\end{array}$ & $\begin{array}{l}4.64 \\
(0.07)\end{array}$ \\
\hline Thymus zygis & $\begin{array}{l}1.64 \\
\quad(0.03)\end{array}$ & $\begin{array}{l}0.62 \\
\quad(0.02)\end{array}$ & $\begin{array}{l}3.0 \\
\quad(0.1)\end{array}$ & $\begin{array}{l}1.88 \\
(0.04)\end{array}$ & $\begin{array}{l}1.34 \\
(0.04)\end{array}$ & $\begin{array}{l}\mathbf{J} .44 \\
(0.04)\end{array}$ & $\begin{array}{l}29.8 \\
\quad(0.2)\end{array}$ & $\begin{array}{l}5.2 \\
\quad(0.4)\end{array}$ & 12 & 46 & $\begin{array}{l}14.6 \\
(0.2)\end{array}$ & $\begin{array}{l}2.54 \\
\quad(0.07)\end{array}$ & $\begin{array}{l}9.5 \\
\quad(0.08)\end{array}$ & $\begin{array}{l}6.4 \\
(0.9)\end{array}$ & $\begin{array}{l}1.0 \\
\quad(0.3)\end{array}$ & $\begin{array}{l}0.77 \\
(0.01)\end{array}$ & $\begin{array}{l}1.63 \\
(0.04)\end{array}$ & $\begin{array}{l}0.92 \\
(0.05)\end{array}$ \\
\hline Thrsetum ovatum & $\begin{array}{l}2.15 \\
(0.03)\end{array}$ & $\begin{array}{l}0.109 \\
(0.005)\end{array}$ & $\begin{array}{l}61.10 \\
(0.07)\end{array}$ & $\begin{array}{l}7.0 \\
(0.1)\end{array}$ & $\begin{array}{l}1.30 \\
(0.02)\end{array}$ & $\begin{array}{l}48.89 \\
(0.03)\end{array}$ & $\begin{array}{l}4.2 \\
(0.2)\end{array}$ & $\begin{array}{l}2.45 \\
(0.05)\end{array}$ & $\begin{array}{l}13.5 \\
(0.5)\end{array}$ & 50 & $\begin{array}{l}3.00 \\
(0.02)\end{array}$ & $\begin{array}{r}295.9 \\
(0.2)\end{array}$ & $\begin{array}{l}42.5 \\
(0.4)\end{array}$ & $\begin{array}{l}5.0 \\
(0.1)\end{array}$ & $\begin{array}{c}268 \\
(6)\end{array}$ & $\begin{array}{l}4.12 \\
(0.06)\end{array}$ & $\begin{array}{l}1.98 \\
(0.04)\end{array}$ & $\begin{array}{l}157 \\
\text { (1) }\end{array}$ \\
\hline
\end{tabular}

n.d. = not detected; Concentrations given in this table must be multiplied by the exponential notation indicated in the corresponding colunn 
aboveground parts of $C$. telephilfolia and $D$. thapsi (approximately $200 \mu \mathrm{g} \mathrm{g}^{-1}$ ). Regarding As, the highest levels were found in the species $C$, telephiifolia $\left(1,350\right.$ and $2,110 \mu \mathrm{g} \mathrm{g}^{-1}$ in roots and aboveground parts, respectively) and in the roots of $R$. acetosella and $A$. album, with approximately $1,000 \mu \mathrm{g} \mathrm{g}^{-1}$. The species $C$. telephiifolia and $D$. thapsi showed an efficient translocation from roots to aboveground parts of these toxic elements.

Therefore, many of the plant samples growing in polluted soils showed high concentration levels of As and heavy metals, mainly in roots, due to soil-plant transfer processes. In some plant species, metal retention in roots has been attributed to metalbinding components, probably proteins, which have been claimed to play an important role in the metal tolerance of species growing in metal-polluted environments (Alvarenga et al. 2004). Zinc showed a more efficient transfer from roots to aboveground parts, probably because it is required in metabolic functions such as carbohydrate, nucleic acid, and lipid metabolism (Kabata-Pendias 2004). The species $D$. thapsi and C. telephiffolia showed the highest $\mathrm{Cu}, \mathrm{Pb}$, and As levels in their aboveground parts, due to an efficient transfer from roots. The essentiality and biological functions of $\mathrm{Cu}$ are well known (KabataPendias 2004), whereas $\mathrm{As}$ and $\mathrm{Pb}$ are not considered essential elements for plants. Therefore, these plant species are able to survive with high essential and toxic element concentration levels in their tissues, without toxicity symptoms.

\subsection{Element Extractability in Soils}

Concentrations determined by chemical analysis using soft extractant agents and single or sequential extractions are more suitable than total element concentration to assess element transfer from soils to plants, animals, or water (Menzies et al. 2007). Weak neutral salt solutions have been reported to be useful to evaluate the impact of trace elements on plants and soil biological activity (Kabata-Pendias 2004), and $\mathrm{CaCl}_{2}$ and phosphate buffer has been successfully used for this purpose (Antosiewicz et al. 2008; Lambrechts et al. 2011; Houba et al. 2000; Pueyo et al. 2005).

The extractable $\mathrm{As}, \mathrm{Cd}, \mathrm{Cr}, \mathrm{Cu}, \mathrm{Pb}$, and $\mathrm{Zn}$ in soils, calculated as the percentage of extracted concentration with respect to the total present in the soil below each plant species, are shown in Fig. 1. In general, the results obtained showed element extraction percentages lower than $10 \%$ (very low in the case of $\mathrm{Pb}$ and $\mathrm{Cr}$ ), with higher values for $\mathrm{As}, \mathrm{Cd}, \mathrm{Cu}$, and $\mathrm{Zn}$ for the soil samples corresponding to some plants. The highest percentage of extractable elements was found for $\mathrm{Cd}$, and the lowest for $\mathrm{Pb}$ and $\mathrm{Cr}$, showing the higher environmental risk posed by $\mathrm{Cd}$, despite its lower total concentration levels in soils, in agreement
Fig. 1 Extractable As, Cd, $\mathrm{Cr}, \mathrm{Cu}, \mathrm{Pb}$, and $\mathrm{Zn}$ in soils, calculated as extracted concentration/tolal concentration ratio, in percentage, for the soils comesponding to different plant species growing in the surrounding of the Mónica mine

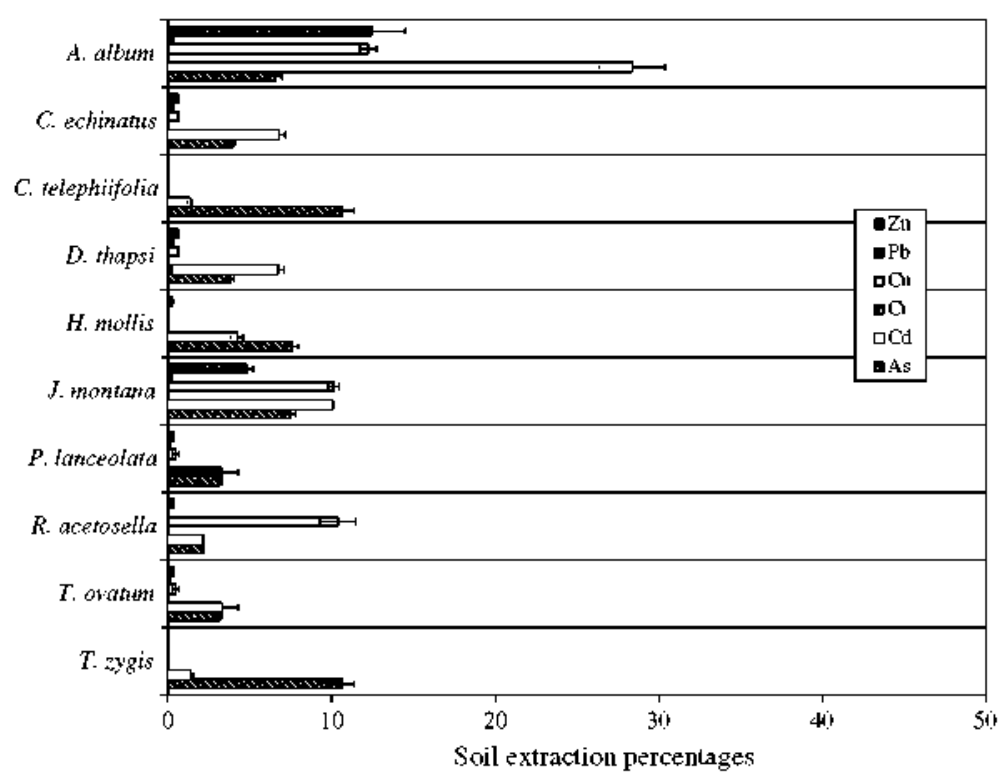


with Moreno-Jiménez et al. (2009). In the case of As, the extractable percentages obtained lower than $14 \%$ agree with Conesa et al. (2008), who reported that in mining-affected soils, where As is a constituent of the least soluble fraction (arsenopyrite), more than 70$90 \%$ of As could be in the most ineit fractions. However, these extractable percentages for As correspond to extractable concentrations between 40 and $200 \mu \mathrm{g} \mathrm{g}^{-1}$, so the environmental risk due to arsenic mobility is relevant to consider:

Metal availability in soils is generally controlled by total metal concentration, $\mathrm{pH}$, and organic matter (Adriano 2001). In our stidy, taking into account that $\mathrm{pH}$ and organic matter values obtained for polluted soil samples studied were similar, a linear regression analysis between extracted and total element concentrations in soils was performed. Pearson's coefficients obtained were $0.47,0.81,0.87,0.88$, and 0.98 for $\mathrm{Cu}$, $\mathrm{Pb}, \mathrm{Cd}, \mathrm{Zn}$, and As, respectively. A highly significant correlation was observed between total and extractable element concentrations in soils $(P<0.05)$, except for $\mathrm{Cu}$, indicating that total concentration is the most relevant factor for element mobility in these soils.

In order to study element phytoavailability, total and extracted metal concentrations were conrelated with metal concentrations in plant tissues. Higher positive conrelations were obtained for plant element concentrations, both for aboveground parts and roots, and their extractable fraction in soils than for the total element concentration, indicating that phytoavailability is better predicted by the extractable fraction than by the total metal concentrations, in agreement with Menzies et al. (2007). Extractable Zn, and As at lower confidence level, were better correlated with root concentrations (Pearson's coefficients of $0.88(P<0.001)$ and $0.63(P<$ $0.1)$ for $\mathrm{Zn}$ and As, respectively), whereas extractable Cd was moderately correlated with aboveground part concentrations (Pearson's coefficient of $0.67(P<$ 0.05)). Therefore, the $\mathrm{CaCl}_{2}$ extraction method seems to be suitable to assess the bioavailable $\mathrm{Zn}$ fraction for plants. However, as expected, phytoavailability of arsenic and of the rest of the heavy metals studied depends on the plant species and not only on the element mobility in soils.

\subsection{Element Uptake and Accumulation in Plants}

Transfer mechanisms and accumulation behaviors in plants have been extensively described and discussed by several authors. From this work, three ratios of concentration for a certain element were found to be significant (Baker 1981; Farago and Merha 1991): (1) root/soil $(R / S)$ or bioavailability factor, which provides information on the bioavailability of the element; (2) aboveground part/root $(A P / R)$ or translocation factor; which provides information about element root-aboveground part transfer; and (3) aboveground part/soil $(A P / S)$ or accumulation factor, which is dependent on the previous ratios and supplies information about the accumulation in the plant. The translocation factors $(A P /$ $R=$ [element $]_{\text {aboveground parr }}$ [element $]_{\text {root }}$ ), accumulation factors $\left(A P / S=[\text { element }]_{\text {aboveground parr }}(\text { element }]_{\text {soil }}\right)$, and bioavailability factors $\left(R / S=[\text { element }]_{\text {roon }} /[\text { element }]_{\text {siri }}\right)$ for As, $\mathrm{Cd}, \mathrm{Cr}, \mathrm{Cl}, \mathrm{Pb}$, and $\mathrm{Zn}$ in different plant species growing in soils surrounding the Mónica mine are shown in Figs. 2, 3, and 4, respectively.

According to Baker (1981), a translocation factor $(A P / R)$ higher than 1 is characteristic of accumulator plants. In this study, significant root-aboveground part transfer was observed in four plant species for $\mathbf{Z n}$ (C. telephiifolia, T zygis, J. montana, and D. thapsi), one for $\mathrm{Cu}$ (D. thapsi), and two for $\mathrm{As}, \mathrm{Cr}$, and $\mathrm{Pb}(C$. telephiifotia and $D$. thapsi). However, the translocation factor should not be considered the only feature of accumulator plants. The $A P / S$ concentration ratio (accumulation factor) is another important factor when considering the phytoremediator potential of a plant species, as well as high element contents in aboveground parts (Alvarenga et al. 2004; Haque et al. 2008). From these considerations, only the species $J$. montana for $\mathrm{Zn}$ and C. telephifiolia for $\mathrm{Pb}$ and $\mathrm{As}$ could be considered accumulator plants.

In the case of $J$. montana, the translocation (Fig. 2) and accumulation (Fig. 3) factors for $\mathrm{Zn}$ were $1.69 \pm$ 0.06 and $2.08 \pm 0.06$, respectively, although $\mathrm{Zn}$ concentration in aboveground parts exceeded in only about $100 \mu \mathrm{g} \mathrm{g}^{-1}$ the normal levels found in plants. This plant species can be considered as a $\mathrm{Zn}$ accumulator; but its behavior is not remarkable due to the moderately high levels found, and from that, $\mathbf{Z n}$ is an essential element for plants.

On the other hand, this species presented high accumulation and bioavailability factors for $\mathrm{Cd}(14.6 \pm$ 0.3 (Fig. 3) and $33.7 \pm 0.4$ (Fig. 4), respectively), although it was not considered a $\mathrm{Cd}$ accumulator since its translocation factor was lower than $1(0.433 \pm 0.008$, Fig. 2). However, this plant species seems to reduce $\mathrm{Cd}$ concentration level in soil, due to its high $R / S$ ratio, Cd 
Fig. 2 Translocation factor $\left(A P / R=[\text { element }]_{\text {aboveground part }}\right.$ [element $]_{\text {root }}$ ) for $\mathrm{As}, \mathrm{Cd}, \mathrm{Cr}$, $\mathrm{Cu}, \mathrm{Pb}$, and $\mathrm{Zn}$ in different plant species growing in soils surrounding the Mónica mine

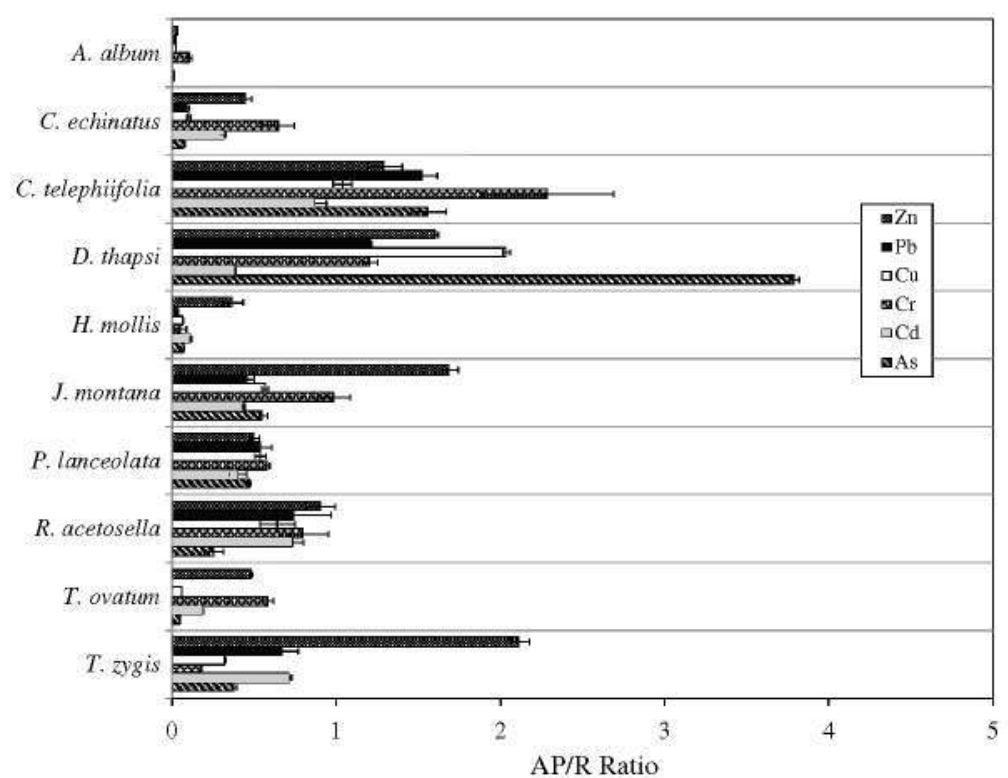

extraction percentage about $10 \%$ (Fig. 1), and the total Cd concentration found in its soil $\left(2.69 \pm 0.03 \mu \mathrm{g} \mathrm{g}^{-1}\right.$, Table 4), which is one of the lowest total $\mathrm{Cd}$ concentration in polluted soils studied.

The accumulation of $\mathrm{Pb}$ in C. telephiifolia satisfied all the above-mentioned criteria. This species presented a high concentration level in the aboveground parts (about $300 \mu \mathrm{g} \mathrm{g}^{-1}$ ), with a translocation factor of $1.53 \pm 0.09$ (Fig. 2), and a high accumulation factor $(17 \pm 3$, Fig. 3). Taking into account that the $\mathrm{Pb}$ concentration found in the soil was close to VR90, it can be considered that $C$. telephiifolia probably reduced the $\mathrm{Pb}$ level in soil due to a phytoextraction process.

The case of As accumulation in C. telephiifolia is notable. Its accumulation factor $(6.8 \pm 0.4$, Fig. 3$)$ was much higher than the range of $A P / S$ values for As reported as normal (0.0001-0.1; Warren et al. 2003). Furthermore, its translocation factor was $1.6 \pm 0.1$ (Fig. 2), one of the highest values found for $A P / R$ ratios together with the corresponding to $D$. thapsi, and the As content in the aboveground parts was high
Fig. 3 Accumulation factor $\left(A P / S=[\text { element }]_{\text {aboveground part }}\right.$ [element $]_{\text {soil }}$ ) for $\mathrm{As}, \mathrm{Cd}, \mathrm{Cr}$, $\mathrm{Cu}, \mathrm{Pb}$, and $\mathrm{Zn}$ in different plant species growing in soils surrounding the Mónica mine

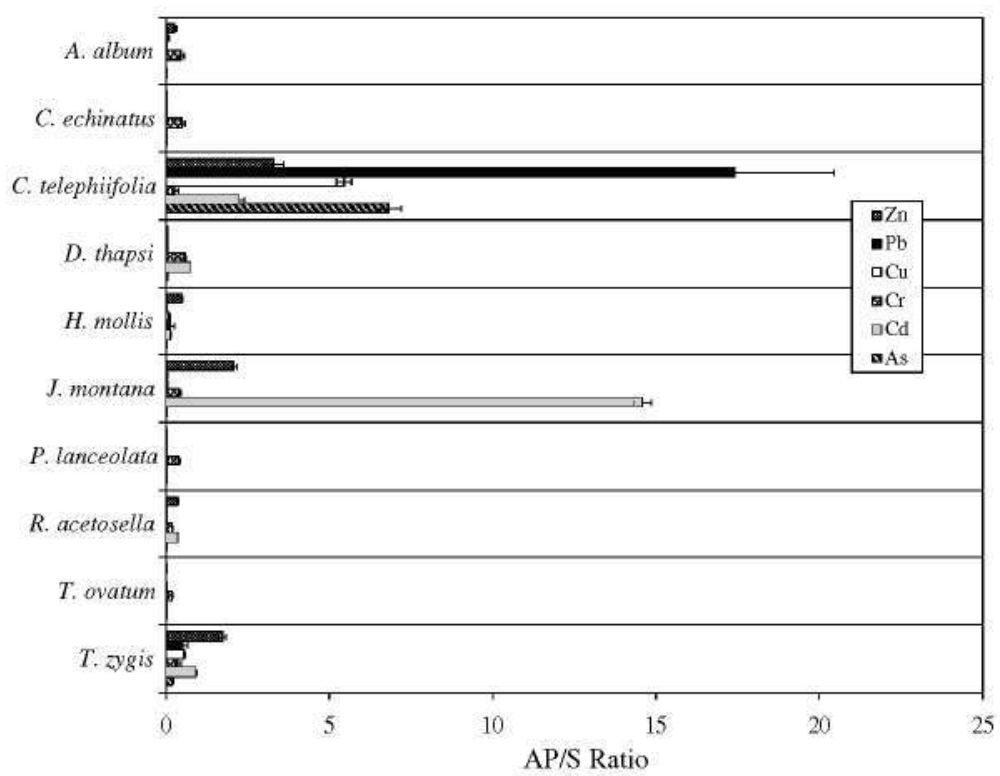


Fig. 4 Bioavailability factor $(R / S=\text { [element }]_{\text {root }}$ [element $]_{\text {soil }}$ ) for $\mathrm{As}, \mathrm{Cd}, \mathrm{Cr}$, $\mathrm{Cu}, \mathrm{Pb}$, and $\mathrm{Zn}$ in different plant species growing in soils surrounding the Mónica mine

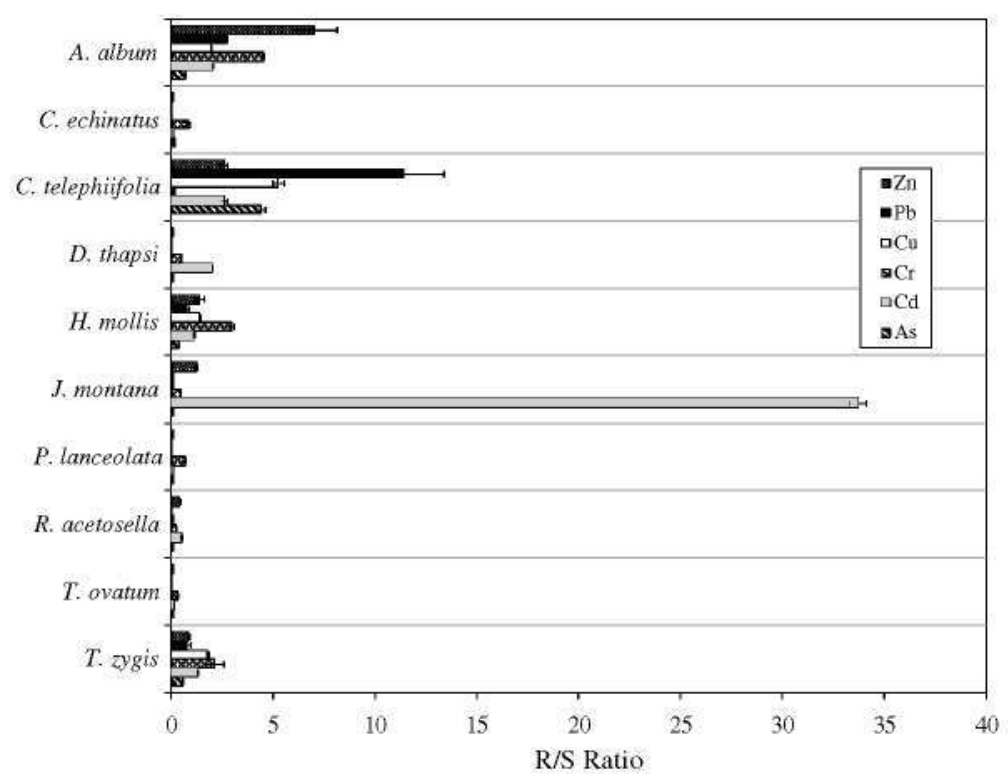

(about 2,000 $\mathrm{g} \mathrm{g} \mathrm{g}^{-1}$ ). The soil corresponding to this plant presented one of the lowest total As concentration from polluted soils and the highest As extraction percentage $(10.9 \pm 0.7 \%$, Fig. 1$)$, also measured by the $R / S$ ratio $(4.4 \pm 0.2$, Fig. 4$)$. This fact made us suspect that $C$. telephiifolia might have solubilized arsenic from soil, making it more bioavailable for uptake, therefore reducing the As concentration level in soil.

On the other hand, the species D. thapsi has been previously reported as $\mathrm{Cd}$ and $\mathrm{Zn}$ accumulator (Moreno-Jiménez et al. 2009). This fact was not observed in this research, but the behavior shown by this species was worthy of attention. Although $D$. thapsi presented the highest $\mathrm{Cd}$ concentration level found in plants, $\mathrm{Cd}$ translocation was not observed. This species also showed the highest $\mathrm{Cu}$ and $\mathrm{Zn}$ contents, as well as high $\mathrm{As}, \mathrm{Cr}$, and $\mathrm{Pb}$ concentration levels in aboveground parts, together with translocation factors higher than 1 for these elements (Fig. 2). However, taking into account that the accumulation factors were very low ( $<1$ for $\mathrm{Cr}$ and $<0.1$ for $\mathrm{As}, \mathrm{Cu}$, $\mathrm{Pb}$, and $\mathrm{Zn}$; Fig. 3), it could not be considered an accumulator plant. According to Alvarenga et al. (2004), low accumulation factors may be due to the saturation of metal uptake when internal concentrations were high, especially for plants growing in highly polluted soils, and this could be the case for $D$. thapsi. It was collected in a site with the highest $\mathrm{Cu}$, $\mathrm{Pb}$, and $\mathrm{Zn}$ concentrations, as well as very high $\mathrm{As}$ level, and this fact could have affected the plant/soil ratios. From this research, we can conclude that the species $D$. thapsi showed a very efficient ability to transfer elements from roots to aboveground parts, and it has developed a tolerance mechanism to grow in highly polluted soils.

\section{Conclusions}

Several plants collected in the vicinity of the Mónica mine presented high arsenic and heavy metal levels in their roots and aboveground parts, showing a capacity to grow in polluted soils without toxicity symptoms. Soils below the plants presented elevated concentrations of $\mathrm{Cd}, \mathrm{Cu}, \mathrm{Pb}$, and $\mathrm{Zn}$ and very high levels of As, in samples collected from polluted areas. In contrast, the levels of these elements found in soil samples from unpolluted areas were low. Total element concentration is the main factor conditioning element extractability, except for $\mathrm{Cu}$. The $\mathrm{CaCl}_{2}$ extraction method seems to be suitable to assess the bioavailable $\mathrm{Zn}$ fraction for plants. However, phytoavailability of arsenic and of the rest of heavy metals studied depends on the plant species and not only to the element mobility in soils.

The high element concentrations found in soils and plants reflect the potential risk remaining due to the past mining activities. From the results obtained in the plant species studied, the behavior shown by $C$. telephiifolia (family Caryophyllaceae) was significant 
because it has not been previously described in the literature as $\mathbf{P b}$ accumulator and As hyperaccumulator Nevertheless, additional research is needed to assess the capacity of continual phytoextraction in contaminated soils on a long-term basis.

Acknowledgments This work was financially suppoited by the Universidad Politécnica de Madrid (project 188/0065815-146) and Ministerio de Educación y Ciencia (project CTM200766432). The authors are grateful to Dr. Pastor Piñeiro and Dr. Gonzaga Garcia-Montero, for helping in the collection and identification of plant samples, and to Dr. Luis Jordá Bordehore and Mr. Rafael Jordá Bordehore for information on the mine site, as well as to the Excelentisino Ayuntamiento de Bustarviejo for admittance to the mine zone and the facilities offered.

\section{References}

Adriano, D. C. (2001). Trace elements in the ternestrial environment. Biogeochenistry, bioavailability and risks of metals (2nd ed.). New York: Springer.

Alkorta, I., Heinández-Allica, J., Becenil, J. M., Amezaga, I., Albizu, 1., \& Garbisu, C. (2004). Recent findings on the phytoremediation of soils contaminated with environmentally toxic heavy metals and metalloids such as $\mathrm{Zn}, \mathrm{Cd}$, $\mathrm{Pb}$, and As. Reviews in Environmental Science and Biotechnologv, 3, 71-90.

Alvarenga, P. M., Araújo, M. F., \& Silva, J. A. L. (2004), Elemental uplake and root-leaves transfer in Cistus ladanifer $\mathrm{L}$. growing in a contaminated pyrite mining area (Aljustrel-Portugal). Wite; Air; and Soil Pollution, 152, $81-96$.

Anawar, H. M., Garcia-Sánchez, A., \& Santa Regina, I. (2008). Evaluation of various chemical extraction methods to estimate plant-ayailable arsenic in mine soils. Chemosphere, $70,1459-1467$.

Anlosiewicz, D. M., Escudè-Duran, C., Wierzlowska, E., \& Sklodowska, A. (2008). Indigenous plant species with the potential for the phytoremediation of arsenic and metals contaninated soils. Woter, Air and Soil Pollution, 19.3, 197-210.

Baker, A. J. M. (1981). Accumulators and excluders-strategies in the response of plants to heavy metals. Journal of Plant Nutrition, 3, 643-654.

Bhatiacharya, P., Welch, A. H., Stollenwerk, K. G., McLaughlin, M. J., Bundschuh, J., \& Panaullah, G. (2007). As in the environment: biology and chemisty. Science of the Fotal Envinonnent, 379, 109-120.

Butcher, D. J. (2009). Phyloremediation of arsenic: fundamental studies, practical applications, and future prospects. Applied Spectroscopy Review's, 44(6), 534-551.

Conesa, H. M., Robinson, B. H., Schulin, B., \& Nowack, B. (2008). Metal extractability in acidic and neutral mine tailings from the Cartagena-La Unión Mining District (SE Spain). Applied Geochemisty, 23, 1232-1240.

Farago, M. E., \& Metha, A. (1991). Uptake of elements by the copper-tolerant plant Armeria maritime. In: Merian E. (ed.) Metal compounds in environment and life-interrelation between chemisty and biology 4 (pp. 163-169).

García-Salgado, S., Qujjano-Nieto, M. A., \& Bonilla-Simón, M. M. (2009). Análisis multielemental mediante ICP-AES de plantas autóctonas procedentes de la zona minera de Bustaryiejo (Madrid). Ministerio de Medio Ambiente $y$ Medio Rural y Marino, Iberolab Libro de Comunicaciones, $V$ Congreso Virtual beroamericano sobre Gestión de Calidad en Laboratorios, 361-366 (http://wwwiberolab.org).

Gisber, C., Almela, C., Vélez, D., López-Moya, J. R., de Haro, A., Serrano, R., Montoro, R., \& Navarro-Aviñó, J. (2008), Identification of As accumulation plant species growing on highly contaminated soils. International Journal of Phytormediation, 10, 185-196.

González del Tanago-Chanrai, J., \& González del Tanago-del Río, J. (2002). Minerales y minas de Madrid. Madrid: Mundj-Prensa.

Haque, N., Peralta-Videa, J. R., Jones, G. L., Gill, T. E., \& Gardea-Torresdey, J. L. (2008). Screening the phytoremediation potential of desert broom (Baccharis sarothroides Gray) growing on mine tailings in Arizona, USA. Environmental Pollation, 153, 362-368.

Houla, V. J. G., Temminghoff, E. J. M., Gaikhorst, G. A., \& van bark, W. (2000). Soil analysis procedures using $0.01 \mathrm{M}$ calcium chloride as extraction reagent. Communications in Soil Science and Plant Analysis, 31(9\&10), 1299-1396.

Jiménez, R., Jordá, L., Jordá, R., \& Prado, P. (2004). Madrid. La minería metálica desde 1417 hasta nuestros días. Bocamina, 14, 50-89.

Kabata-Pendias, A. (2001). Trace elements in plants. In A. Kabata-Pendias (Ed.), Trace elements in soils and plants (3rd ed., pp. 73-98). Boca Raton: CRC Press.

Kabata-Pendias, A. (2004). Soil-plant transfer of trace elementsan environmental issue. Geoderma, 122, 143-149.

Lambrechts, T., Couder, E., Bemal, M. P., Faz, A., Iserentant, I., \& Lutts, S. (2011). Assessment of heavy metal bioavailability in contaminated soils from a former mining area (La Union, Spain) using a rhizospheric test. Water, Air, and Soll Pollution, 217, 333-346.

Lasat, M. M. (2002). Phytoextraction of toxic melals: a review of biological mechanisms. Joumal of Environmental Quality, 31, 109-120.

Mahmud, R., Inoue, N., Kasajima, S., \& Shaheen, R. (2008). Assessment of the polential indigenous plant species for the phytoremediation of arsenic contaninated areas of Bangladesh. International Joumal of Phytormediation, 10, 119-132.

MAPA (1994). Determinación de carbono orgánico oxidable. Métodos oficiales de análisis de suelos vaguas para riego, bl. HI Ministerio de Agricultura, Pesca y Alimentación. Madrid, Spain, pp. 281-283.

Menzies, N. W. Donn, M. J., \& Kopitike, P. M. (2007). Evaluation of extractants for estimation of the phytoavailable trace metals in soils. Envizonmental Polhation, 145, $121-130$.

Moreno-Jiménez, E., Manzano, R., Esteban, E., \& Peñalosa, J. (2010). The fate of arsenic in soils adjacent to an old mine site (Bustarviejo, Spain): mobility and transfer to native flora. Journal of Soils and Sediments, 10, 301-312.

Moreno-Jiménez, E., Peñalosa, J. M., Manzano, R., CarpenaRuíz, R. O., Gamarra, R., \& Esteban, E. (2009). Heavy 
metals distribution in soils surrounding an abandoned mine in NW Madrid (Spain) and their transference to wild flora. Journal of Hazarlous Materials, 162, 854-859.

ORD 2770/2006 MAD (2006) Orden 2770/2006, de 11 de agosto, Consejería de Medio Ambiente y Ordenación del Territorio, Comunidad de Madrid, B.O.C.M. Núm. 204, Lunes 28 de agosto de 2006. pp. 29-30.

Padmavathianıma, P. K., \& Li, L. Y. (2007). Phytoremediation technology: hyper-accumulation metals in plants. Witer; Air; and Soll Pollution, 184, 105-126.

Pastor, J., García-Salgado, S., Hemández, A. J., Quijano-Nieto, M. A., \& Bonila-Simon, M. M. (2008). Assénico y otros metales pesados en plantas de comunidades de pastos del cerro de la plata (Bustarviejo, Maktid). In: Femández, P et al. (Eds.) Pastos, clave en la gestión de los territorios. Consejería de Agicultura y Pesca, Junia de Andahuía (pp. 91-97).

Pastor, J., \& Hemández, A. J. (2008). Contenidos de metales pesados en gramineas de ecosistemas desarollados sobre antiguas minas abandonadas de Madrid y Castilla-La Mancha. $9^{\circ} \mathrm{Congreso}$ Nacional del Medio Ambiente.

Pilon-Smits, E. A. H. (2005). Phyloremediation. Annual Review of Plant Biology, 56, 15-39.

Pueyo, M., López-Sánchez, J. F., \& Rauret, G. (2004). Assessment of $\mathrm{CaCl}_{2}, \mathrm{NaNO}_{3}$ and $\mathrm{NH}_{4} \mathrm{NO}_{3}$ exiraction procedures for the study of $\mathrm{Cd}, \mathrm{Cu}, \mathrm{Pb}$ and $\mathrm{Zn}$ extraciability in contaninated soils. Analvica Chimica Acta, 504, 217-226.

Pueyo, M., Sahuquillo, A., Rigol, A., López-Sánchez, J. F., \& Rauret, G. (2005). A new quality control soil material for monitoring trace metals in accidentally polluted areas. Analvtica Chimica Acta, 533, 41-49.

Rao, C. R. M., Sahuqnillo, A., \& López Sanchez, J. F. (2008). A review of the different methods applied in environmen- tal geochemistry for single and sequential extraction of trace elements in soils and related materials. Water; Air; and Soil Pollution, 189, 291-333.

Sahuquillo, A., Rigol, A., \& Rauret, G. (2003). Overview of the use of leaching/extraction tests for risk assessment of trace metals in contaminated soils and sediments. THAC Trends in Analytical Chemistry, 22, 152-159.

Sridhar, B. B. M., Han, F. X., Diehl, S. V., Monis, D. L., \& Su, $\mathrm{Y}$ (2007). Monitoring the effects of $\mathrm{As}$ and $\mathrm{Cr}$ accumulation in Chinese brake fem (Pteris vittata). International Journal of Remote Sensing, 28, 1055-1067.

Takeda, A., Tsukada, H., Takaku, Y., Hisamatsu, S., Inaba, J., \& Nanzyo, M. (2006). Extractability of major and trace elements from agricultural soils nsing chemical extraction methods: application for phyloavailability assessment. Soil Science and Plant Nutrition, 52(4), 406-417.

UNE 103-300 (1993) Deteminación de la humedad de wn suelo mediante secado en estura.

UNE 77305 (1999) Calidad del suelo; Determinación del pH.

UNE 77308 (2001) Calidad del suelo: Determinación de la conductividad eléctrica especifica.

Vámerali, T., Bandiera, M., \& Mosca, G. (2010). Field crops for phytoremediation of metal-coniaminated land. A review, Envinonmental Chenistry Letters, 8, 1-17.

Warren, G. P., Alloway, B. J., Lepp, N. W, Singh, B., Bochereau, F. J. M., \& Peuny, C. (2003). Field trials to assess the uplake of arsenic by vegetables from contanimated soils and soil remediation with iron oxides. Science of the Bal Enviromment, 311, 19-33.

Zhao, F. J., Ma, J. F., Meharg, A. A., \& McGrath, S. P. (2009). Arsenic nptake and metabolism in plants. The New Phvtologist, 181, 777-794. 